\title{
Branding in practice, or how an Amsterdam publisher used the city to promote Gerbrand Bredero (1585-1618)
}

\author{
Jeroen Jansen $^{* \dagger}$ (D) \\ Universiteit van Amsterdam, Neerlandistiek, Spuistraat 134, 1012 VB Amsterdam, Netherlands \\ ${ }^{\star}$ Corresponding author. Email: j.jansen@uva.nl
}

\begin{abstract}
This article explores how the publisher Cornelis vander Plasse managed to promote the literary career of the Dutch playwright Gerbrand Bredero (1585-1618) by using Amsterdam as a place. It is concerned with the way in which this Amsterdam-based publisher took decisions both to comply with Bredero's work and to derive maximum benefit from its publication. One of his strategies was to deploy the city as a recognizable trademark to Bredero's work. By using the advantages that the 'place' of Amsterdam offered him, he proved himself an expert in marketing and advertising, laying the foundation of Bredero's reputation as both an Amsterdam-based and national author in the centuries to follow.
\end{abstract}

'Do publishing houses influence the literary canon?' With this question, Frank de Glas identified five ways in which literary publishing houses can influence the reputation of their authors: (1) through their selection of specific titles; (2) by improving the quality of a text; (3) through the effect their own reputation has on the reception of literary works; (4) by optimizing the commercial exploitation of an author's oeuvre; and (5) through their relations with the book trade, the 'intermediaries' and the buyers and readers of books. ${ }^{1}$ De Glas concluded that 'only a few publishing houses have enough stability and sufficient stamina to achieve a lasting effect on the canonization of authors who were launched by them long ago.' ${ }^{2}$ These five possibilities and the corresponding conclusion concern the publishing process in the second half of the twentieth century, a period in which national discourse was far more important than the interests of individual cities. This article seeks to examine the situation in early modern Amsterdam by analysing the activities of the publisher Cornelis Lodewijcksz. vander Plasse (1585-1641) to boost the reputation of his former schoolmate Gerbrand Adriaensz. Bredero (1585-1618).

\footnotetext{
${ }^{\dagger}$ An earlier draft of this article was presented at the annual meeting of the Werkgroep Zeventiende Eeuw (August 2018) in Dordrecht, Netherlands. I am indebted to Esther van Andel, Helmer Helmers and the anonymous reviewers for their helpful comments.

${ }^{1}$ F. de Glas, 'Hebben uitgeverijen invloed op de literaire canon?', Spiegel der letteren, 34 (1992), 289-304.

${ }^{2}$ Ibid., 303.

(C) The Author(s), 2021. Published by Cambridge University Press. This is an Open Access article, distributed under the terms of the Creative Commons Attribution licence (http://creativecommons.org/licenses/by/4.0/), which permits unrestricted re-use, distribution, and reproduction in any medium, provided the original work is properly cited.
} 
Bredero became one of the most popular and well-known authors from this period and belongs to today's literary canon. ${ }^{3}$ This article will show how Vander Plasse managed to display Bredero's talent to his fellow Amsterdam citizens and to their descendants by way of the city.

Not much is known about the life of either man. In the recent biography (2018) of Bredero, René van Stipriaan has attempted to describe the author's life. ${ }^{4}$ Much of city life from that time has been lost: the performances of Bredero's plays at Amsterdam's chamber of rhetoric De Eglentier (The Eglantine) and in the theatre of the Nederduytsche Academie (Dutch Academy) at the Keizersgracht can no longer be accessed, and hardly any manuscripts have survived. Besides a posthumous portrait and some scattered archival material, ${ }^{5}$ Bredero's publications are all that remain. And almost all of these publications, made public during Bredero's life and especially posthumously in the period 1618-39, resulted from the effort and dedication of Vander Plasse. Bredero owes his reputation to this publisher. The latter's activities not only determine what we know about Bredero's work and person, but also how we read his work. ${ }^{6}$

Whereas De Glas suggested five ways of shaping the reputation of an author, the case of Vander Plasse and Bredero highlights only two: 'the influence of the cultural appearance of the publishing house on the reception of literary works' and 'the optimum commercial exploitation of the oeuvre of an author'. Moreover, the contribution of Amsterdam as a brand and as a place will be discussed in this article. Surely, the city was of paramount importance for Bredero and for his publisher. They were born in the same year and brought up in the same area: the 'Old Side' (the east bank of the Amstel), close to the Dam square. The majority of their public - the spectators and readers of Bredero's plays, the singers of his songs and the buyers of his books - came from this city, certainly in the first quarter of the seventeenth century. Amsterdam shaped their world.

In this article, I am especially interested in the different ways the city in all its aspects helped Bredero's permanent publisher to boost the reputation of his fellow townsman. Was the reputation of the publisher also involved here, and if so how? Which aspects of the city and which elements from Bredero's work did he use? To answer these questions I will discuss some publishing marketing strategies related to city branding, and whether Bredero was deliberately branded as an Amsterdam author.

\section{An author and his city: Amsterdam as geographical and cultural capital}

As Paul Hoftijzer has shown in his dissertation on Amsterdam publishers, publishing, printing and bookselling had grown into an extensive and thriving branch of

\footnotetext{
${ }^{3} \mathrm{R}$. van Stipriaan, De hartenjager. Leven, werk en roem van Gerbrandt Adriaensz. Bredero (Amsterdam, 2018), 9.

${ }^{4}$ Ibid.; G. Stuiveling, Memoriaal van Bredero. Documentaire van een dichterleven (Culemborg, 1970). For Vander Plasse, see H. Borst et al., 'Analytische bibliografie en literatuurgeschiedenis. Wonen in het Woord Leven in de letter', Literatuur, 5 (1988), 332-3; P.J. Verkruijsse, http://cf.hum.uva.nl/bookmaster/plasse/index. htm (accessed 15 Jan. 2020).

${ }^{5}$ Collected by Stuiveling, Memoriaal.

${ }^{6}$ See also J. Jansen, 'Drie decennia boekenzorg. Cornelis vander Plasse en Gerbrand Bredero', Jaarboek voor Nederlandse boekgeschiedenis, 26 (2019), 53-77.
} 
commerce in the seventeenth-century Dutch Republic. ${ }^{7}$ The favourable economic climate stimulated the Dutch book trade. Moreover, there was a relatively high degree of freedom, due to the particular political and religious relationships in the Dutch Republic. ${ }^{8}$ Therefore, the output and diversity of book production in this period are impressive: hundreds of printer-publishers were active, producing well over 67,000 titles, most of them in Amsterdam. Falling prices and increased quality and production meant that printed books were becoming a more desirable, affordable and accessible feature of urban life. Amsterdam developed as the primary urban centre for publishers. ${ }^{9}$ The city accommodated many writers of a diverse calibre as well as most of the country's bookshops. Apart from historical, political and religious evidence, this clustering may be explained by the observation that all three dimensions of 'place', as distinguished by John Agnew, ${ }^{10}$ significantly contributed to this development. First, place as spatial location: Amsterdam was an attractive city in Holland, an important trading town on the bank of the river Amstel and IJ, with many transport possibilities, and an appealing prospect in many respects. ${ }^{11}$ Secondly, place as locale, i.e. place as context, place as a setting for social relationships: religious tolerance and an unusual degree of freedom of speech stimulated different social activities and inter-relationships in the city. Thirdly, place as a sense, the emotional connection of people with a place: the citizens knew the different city spaces and the people who lived there. They knew the shops, most of the booksellers, the publishers and authors. They recognized the spots described in literary texts set in Amsterdam. They may have recognized allusions to local situations and persons as well.

All three dimensions are, in their own way, relevant for the early modern city. Several publishers in the Dutch Republic connected authors with their place of origin, as civic pride was culturally and commercially important. But Amsterdam was booming. More than half of all Dutch books were produced there, and the book trade provided a living for many hundreds of Amsterdam people: type founders,

\footnotetext{
${ }^{7}$ For the situation in the Netherlands, see P.G. Hoftijzer, 'The Dutch Republic, centre of the European book trade in the 17th century', European History Online (EGO), published by the Leibniz Institute of European History (IEG) (Mainz 2015), 1-31: http://ieg-ego.eu/en/threads/backgrounds/the-book-market/ paul-g-hoftijzer-the-dutch-republic-centre-of-the-european-book-trade-in-the-17th-century (accessed 15 Jan. 2020). See E.K. Grootes, 'Vondel and Amsterdam', in J. Bloemendal and F.-W. Korsten (eds.), Joost van den Vondel. Dutch playwright in the Golden Age (Leiden, 2012), 101-14. According to C. Rasterhoff, the situation in Amsterdam differed from that in Leiden and The Hague, as the expansion of the Amsterdam book production industry 'only started after 1585 and was fueled by the pulling force of commerce rather than by government initiative' (Painting and Publishing as Cultural Industries. The Fabric of Creativity in the Dutch Republic, 1580-1800 (Amsterdam, 2017), 42).

${ }^{8}$ P.G. Hoftijzer, Engelse boekverkopers bij de beurs: de geschiedenis van de Amsterdamse boekhandels Bruyning en Swart, 1637-1724 (Amsterdam, 1987), 2.

${ }^{9}$ Rasterhoff, Painting and Publishing, 42-3; P.G. Hoftijzer, 'Metropolis of print: the Amsterdam book trade in the seventeenth century', in P.K. O'Brien (ed.), Urban Achievement in Early Modern Europe: Golden Ages in Antwerp, Amsterdam and London (Cambridge, 2001), 249-63; C. Rasterhoff, 'Carrière en concurrentie in een culturele sector. De Amsterdamse boekhandel, 1580-1800', De Zeventiende Eeuw, 27 (2012), 162-79; F. Deen et al., 'Pamphlets and politics: introduction', in idem (eds.), Pamphlets and Politics in the Dutch Republic (Leiden, 2011), 15-17.

${ }^{10}$ J.A. Agnew, Place and Politics: The Geographical Mediation of State and Society (Boston, MA, 1987), 28.

${ }^{11}$ See P. Dijstelberge and P.J. Verkruijsse, 'Een schitterend moeras. Boek en wereld in de zeventiende eeuw', Jaarboek voor Nederlandse boekgeschiedenis, 17 (2010), 141-70.
} 
printers, correctors, booksellers and bookbinders. ${ }^{12}$ Artists were attracted to the metropolis by the opportunities for making a living, settling in the lively, noisy centre around the Dam square. The many bookstores brought together individuals who shared an interest in books of all kinds, and in poetry and plays as well. The city of Amsterdam was at the centre of the Dutch information network and would remain so. ${ }^{13}$ Not only did the producers of books, and the people who helped to deliver those books, live in Amsterdam, but so too did the readers and the collectors. They were attracted by the bookshops and associated publishers out of interest or through emotional engagement with books. Local writers and engravers were well known, just as makers of charts, atlases and globes were, such as the Blaeu family. Amsterdam brimmed with artistic culture. Scattered across the town centre, places appeared where people interested in culture and education came together to discuss literature and the news. The Eglantine can be considered an urban society in which people studied and composed poetry, were trained in writing and performed plays together. At regular intervals, rhetoricians contributed to the festival culture of the municipality. Publications recorded many of these activities.

Some decades ago, De la Fontaine Verwey concluded in an overview of 'Bredero and his city' that Amsterdam life was an endless source of inspiration for this poet. ${ }^{14} \mathrm{He}$ briefly mentioned Vander Plasse, but not what Bredero owed to his childhood friend. Neither did he discuss the fact that the bookshop and the publishing house played a crucial role in the relationship between these men. The shop opened its doors in 1611, the same year in which the author became active at the Amsterdam chamber of rhetoric. Around that time, Bredero's first publications appeared: poems and songs distributed by others among songbooks and other publications. It was the beginning of a decade described in a poem by the famous Dutch poet and playwright P.C. Hooft as 'a golden period' ('gouden tijdt'), due to the efforts undertaken by William of Orange (1533-84), the former leader of the Dutch Revolt. Hooft had every reason for his formulation. William (and his son Maurice) had granted the Netherlands 'a golden freedom' that resulted in the flowering of the Amsterdam stage between 1610 and 1618, comparable to the situation in London some 30 years earlier, when theatres opened their doors and Shakespeare flourished as author and actor. ${ }^{15}$

One of the authors responsible for this 'golden' period was Gerbrand Bredero, who has been justly compared to Shakespeare. ${ }^{16}$ He was brought up in the centre of Amsterdam and must have been aware of the literary developments around him. He lived close to the chamber of rhetoric which performed his plays and Vander Plasse's bookshop which sold them (after 1615). The latter's business was successful, as it was located at a prominent spot near the new-built Bourse (1611), a

\footnotetext{
${ }^{12}$ Hoftijzer, Engelse boekverkopers, 355.

${ }^{13}$ A. der Weduwen, Dutch and Flemish Newspapers of the Seventeenth Century, 1618-1700, vol. I (Leiden, 2017), 15-16.

${ }^{14}$ H. De la Fontaine Verwey, 'Bredero en zijn stad', in G. Stuiveling et al. (eds.), Rondom Bredero. Een viertal verkenningen (Culemborg, 1970), 14ff, 21.

${ }^{15}$ See S. Melissen, 'De heedendaagse Goude-eeuw', Spektator, 11 (1981-82), 42-3; Van Stipriaan, De hartenjager, 271, 277ff.

${ }^{16}$ Van Stipriaan, De hartenjager, 277ff, indicates some strong similarities between both men.
} 


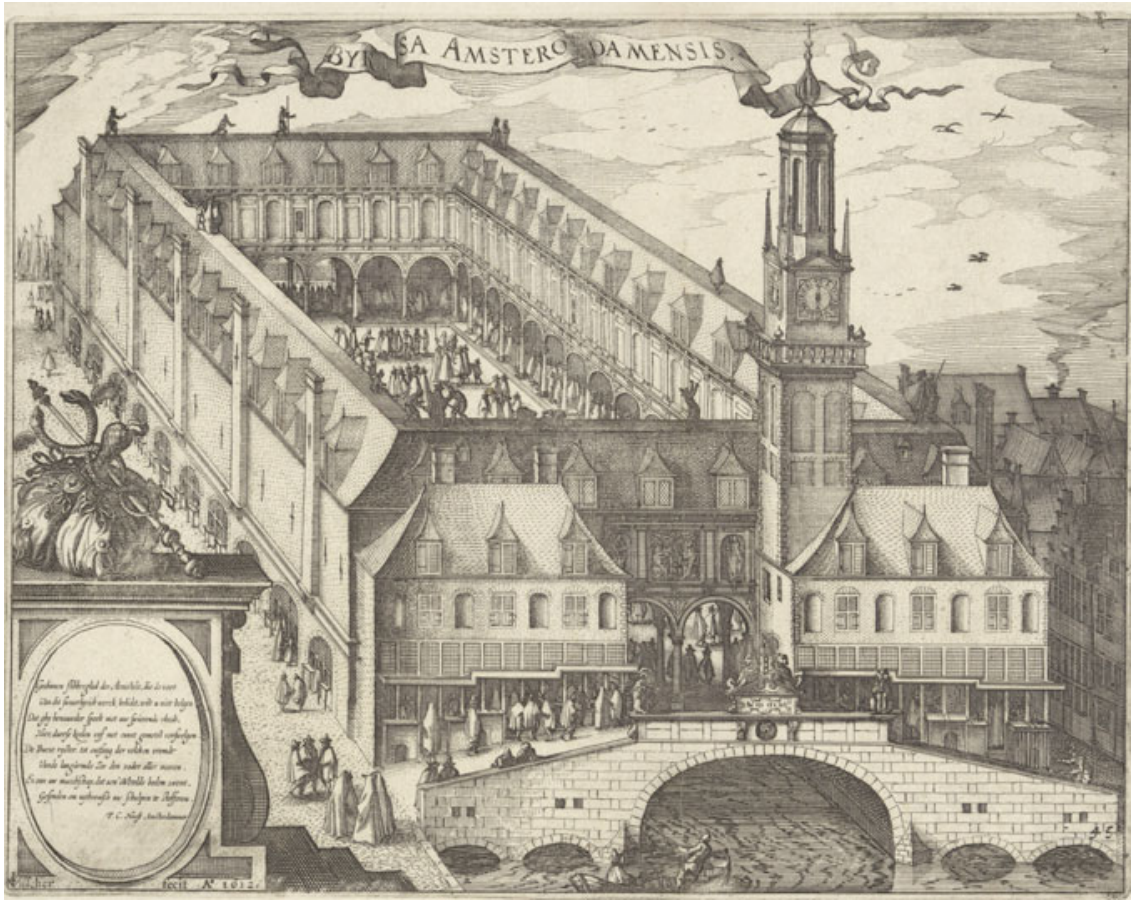

Figure 1. Many bookshops and publishing houses were located around the Amsterdam Bourse in the centre of the city. On the corner, Cornelis vander Plasse started his bookshop in 1611 and somewhat later his publishing house. The Bourse was built by Hendrik de Keyser, Claes Jansz. Visscher (II), 1612. (Rijksmuseum Amsterdam)

crowded place in the centre of town (see Figure 1). ${ }^{17}$ However, judging by the number of books Vander Plasse published annually (see Figure 2), the publishing trade must have been a sideline for him. Like many other book printers and publishers, he profited from the selling of office supplies, such as almanacs, paper and ink, and from the binding of books that customers bought. ${ }^{18}$ Almost all books to which Bredero contributed must have been sold here, from as early as 1612, when Vander Plasse decided to publish the fourth volume in the popular series Tragic Histories ('Tragische Historien'), a translation from the French. He asked Bredero to deal with the poems. ${ }^{19}$

\footnotetext{
${ }^{17}$ When he died in 1641, Vander Plasse owned a substantial number of houses, a few of which his widow sold two years later. See the overview by Verkruijsse: http://cf.hum.uva.nl/bookmaster/plasse/index.htm (accessed 15 Jan. 2020).

${ }^{18}$ M.M. Kleerkooper and W.P. van Stockum Jr, De Boekhandel in Amsterdam voornamelijk in de 17e eeuw (The Hague, 1914-16), 565, 289. Cf. E.K. Grootes, in G.A. Bredero, Schyn-heyligh, ed. E.K. Grootes (The Hague, 1979), 12. In January 1617, Vander Plasse is just called a 'bookseller in Amsterdam' ('bouckvercooper tot Amstelredam'), in a (rejected) patent application. The Hague, NA: Res. St. Gen. 11.01.1617.

${ }^{19}$ See J. Jansen, 'Hoe Bredero's carrière begon', VakTaal, 31 (2018), 7-9.
} 


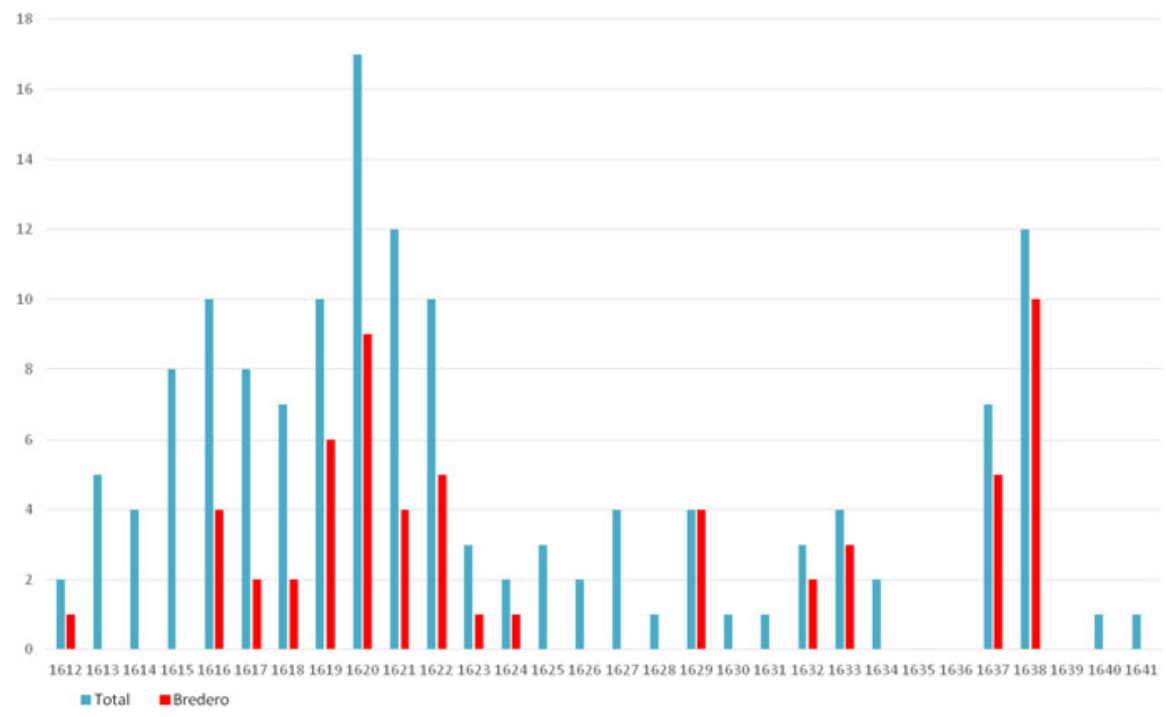

Figure 2. Number of publications by C.L. vander Plasse and the share of Bredero's work in the total number. Information based on the chronological Fondslijst (publisher's list) of Vander Plasse according to P.J. Verkruijsse: http://cf.hum.uva.nl/bookmaster/plasse/index.htm.

Bredero soon climbed the social ladder; due to his literary successes, he became a member of the local chamber of rhetoric, notably at a moment when it opened its doors to the Amsterdam public for theatrical performances around 1610, at the dawn of the 'golden period' of literary and artistic life in Amsterdam. Here, he met local merchants and Amsterdam artists, and fellow writers such as Samuel Coster and P.C. Hooft. But Bredero's reputation was also formed by his awareness of the city's identity. Kevin Lynch has defined 'identity' in its simplest form as 'a sense of place', and as 'the extent to which a person can recognize or recall a place as being distinct from other places, as having a vivid, or unique, or at least a particular, character of its own'. ${ }^{20}$ Each city has a unique identity, comprising images and memories of urban elements such as monumental buildings, public spaces and other special features. ${ }^{21}$ Bredero, who distanced himself from the ambitions of the poeta doctus (poet scholar), let the Amsterdam citizens talk in their own dialect, opting for the living language of his immediate social milieu. This use of Amsterdam dialect and the tangible setting in the city was new. ${ }^{22}$ The dialect was spelled almost phonetically in print. Plays and songs show us a chattering Amsterdam, including cityscapes, buildings, canals and local people. The spectators

\footnotetext{
${ }^{20}$ K. Lynch, Good City Form (Cambridge, MA, 1984), 131; A. Pettegree and A. Der Weduwen, The Bookshop of the World. Making and Trading Books in the Dutch Golden Age (New Haven and London, 2019), 226.

${ }^{21}$ M. Riza, N. Doratli and M. Fasli, 'City branding and identity', Procedia - Social and Behavioral Sciences, 35 (2012), 294.

${ }^{22}$ The use of dialect in (semi-)comical plays, though, has been used earlier in the Netherlands, for example by Jan van Hout, in his Loterijspel (1596). See J. Koppenol, Leids heelal. Het Loterijspel (1596) van Jan van Hout (Hilversum, 1998), 265-8.
} 
and readers must have experienced the feeling, smell, light and soundscape of their Amsterdam. The city's identity is displayed in farces by Bredero, such as that of the Cow and the Miller (written and performed at the chamber in 1612-13, and published by Vander Plasse in 1619), in a comedy The Little Moor (Moortje), that was performed in 1615 (published by Vander Plasse in 1617), in the Spanish Brabanter (1617), staged at the Dutch Academy theatre and published some months later, and in the jocular section of the Merry Song Book (c. 1616). Bredero's transition to realism can be traced through all his works for the stage. Even his 'serious' drama, the tragedy Rodd'rick ende Alphonsus (1611) and tragicomedies, published by Vander Plasse in 1616, contain several comical Amsterdam scenes, presenting characters from the lower social orders. His lyrical works follow the same course, including dialect spoken by peasants of the surrounding districts and by city dwellers.

Bredero's plays and songs were innovative, high-quality and phenomenally popular at the beginning of the seventeenth century. The many books from that period, however, tell only half of the story. Initially, Bredero did not write for publication. The plays were meant for performances at the chamber of rhetoric, the songs to be sung by his fellow citizens. Oral poetry and performances of plays unified individuals. The circulation of poetry in the city's oral culture evidently brought together various classes of people, women, foreigners, artisans and musicians. It is hard to imagine how this orality must have sounded in a busy early modern city. The voices of the performers mixed with common sounds in the streets and marketplaces. People were reading pamphlets aloud, exchanging the latest news and telling stories. Rhetoricians and actors were performing parts of plays in the open air, songs could be heard all over the city, (foreign) merchants were pursuing lucrative trade, civil servants were reading official letters, people were spreading rumours and gossip, market traders and vendors were yelling, eager to sell their merchandise, declaring the best bargains in town. The crowded city was bursting with screaming and swearing servants, nagging maids, lively taverns and quarrelling townsfolk. Consultations and deliberations were everywhere, mixing with the other sounds of the city, such as rattling carts, barking dogs and neighing horses.

\section{Vander Plasse as a publisher}

Amid all this bustle, the bookshop of Vander Plasse opened its doors, right in the city's heart, just a stone's throw from the house where Bredero was born and his later home at the Oudezijds Voorburgwal (a mere 150 metres, to be precise) (see Figure 3). ${ }^{23}$ Although place is often considered in terms of (geographical) proximity, there are other dimensions of place, as discussed before on the basis of Agnew's qualifications. During Bredero's lifetime, the bonds between writer, publisher and city turned their co-operation into a successful enterprise. The two friends easily shared ideas and took decisions. They must have preferred the same specific

\footnotetext{
${ }^{23}$ Kleerkooper and Van Stockum Jr, De Boekhandel in Amsterdam, 564-5; G. Kalff, 'Nieuwe gegevens voor de geschiedenis onzer letterkunde', Tijdschrift voor Nederlandse taal en letterkunde, 36 (1919), 589: 'On 7 May 1611, Cornelis Lodowijcksz van der Plasse, bookbinder, 26 years old, who lived near the new Bourse, entered a notice of marriage' ('7 Mei 1611 ondertrouwden Kornelis Lodowijksensz van der Plassen, boekbinder, oud 26 jaeren, woonende bij de nieu borze'). Borst et al., 'Analytische bibliografie', 332.
} 


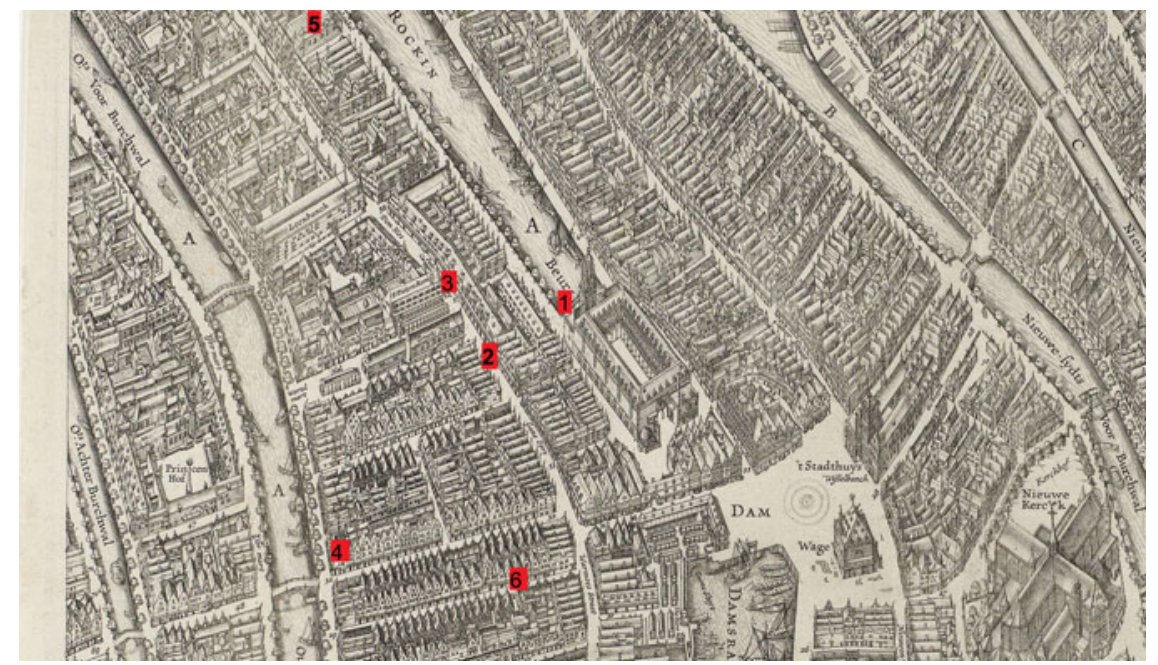

Figure 3. Map (1625) of the centre of Amsterdam (detail), made by Balthasar Florisz van Berckenrode. 1: the bookshop and publishing house of Cornelis vander Plasse, next to the Bourse; 2: the house where Bredero was born; 3: the chamber of rhetoric (Eglantine) in the Nes; 4: the living house of Bredero from 1602; 5: the Nieuwezijds Kapel where Bredero was buried (at the other side of the Rokin); 6: the secondary school where Bredero was educated in the Pijlsteeg. (Rijksmuseum Amsterdam)

locations, such as the Eglantine in the Nes and the Academy at the 'New Side.. ${ }^{24}$ Bredero's plays were performed there and Vander Plasse published them, often stating their performance (date and location) on the title page. Vander Plasse is considered to have been the most important publisher of drama staged at the Academy. ${ }^{25}$ He presented himself as a prominent publisher of Amsterdam writers (including Bredero and Samuel Coster), and participated in an Amsterdam cultural network to which his close family (including his wife Anne) belonged, as well as employees of his publishing house and other contacts. A firm family network was a necessary condition for the publishing company to flourish. ${ }^{26}$ Not only authors, but also engravers, translators, panegyrists and printers (such as Barent Otsz., Cornelis Fransz., Nicolaas Biestkens and Paulus van Ravesteijn) shaped Vander Plasse's commercial network from the beginning. ${ }^{27}$ Due to these

\footnotetext{
${ }^{24}$ Cf. B. Heebels, I. van Aalst and O. Atzema, 'Places, publishers and personal ties: the relational qualities of urban environments for book publishers', in R. Sternberg and G. Krauss (eds.), Handbook of Research on Entrepreneurship and Creativity (Cheltenham, 2014), 255.

${ }^{25}$ P.J. Koopman, 'Nicolaes Biestkens en de Nederduytsche Academie', De zeventiende eeuw, 8 (1992), 124.

${ }^{26} \mathrm{~S}$. van Rossem, Het gevecht met de boeken. De uitgeversstrategieën van de familie Verdussen (Antwerpen, 1589-1689) (Antwerp, 2014), 20 and 23ff; Heebels, Van Aalst and Atzema ('Places, publishers and personal ties', 253-7) distinguish three types of network connections, from private to commercial: communality-relationship (private, trust, personal relationships), sociality-career (professional-private, career-orientated), and connectivity-task (commercial, professional, task-orientated).

${ }^{27}$ Some observations on this topic by P.J. Verkruijsse: http://cf.hum.uva.nl/bookmaster/Bredero\&Starter/ index.htm (accessed 15 Jan. 2020); Dijstelberge and Verkruijsse, 'Een schitterend moeras', 160. Cf. P. Dijstelberge, 'De Cost en de Baet. Uitgeven en drukken in Amsterdam rond 1600', in J.W.J.
} 
collaborations, Amsterdam was of great importance for Vander Plasse from a social and economic perspective. In a dedication addressed to 'de konst-beminnende Lesers' (the art-loving readers) of Bredero's posthumous drama Stommen Ridder (1619), Vander Plasse apologized that he 'and some others' ('en eenighe andere') had not read the story of Palmerin, the source text. No summary of the play was added. The wording 'and some others' could mean that Vander Plasse had looked for someone with knowledge of the Palmerin story within his own circle, but with no result. ${ }^{28}$ So the play was published without the usual plot summary.

'Places are products whose identities and values must be designed and marketed as products', as Kotler et al. have stated. ${ }^{29}$ This is a modern insight, but just as relevant for early seventeenth-century publishers. An important part of the identity of Vander Plasse's publishing was based on the (image of the) city of Amsterdam. An extant fragment of paper shows the publisher's name connected to the city as a small silhouette (see Figure 4). For those who approached Amsterdam from the countryside or from the sea, the towers, churches and steeples marked recollections and connotations. Urban places represent meanings and memories to their inhabitants, as well as identities and associations, as John Montgomery has argued in his article 'Cultural quarters as mechanism for urban regeneration'. 30 There were plenty of spots in central Amsterdam that reflected such meanings for their inhabitants. Some of them must have functioned as trigger points for literary associations. Amsterdam citizens recognized themselves and others in Bredero's comical plays and songs, no matter how strongly the author argued that they did not always reflect his immediate contemporaries or his fellow townsmen. ${ }^{31}$ But the plays were realistically set in and around the city, and mention specific streets, houses, marketplaces, churches and canals. Some of Bredero's songs refer to recognizable places in the city or to notable persons, and to him as a writer personally. In yet another way, the city played a remarkable part in Bredero's oeuvre. The impostors, villains and fools who abound in the plays and songs largely come from outside the city. This does not mean that townspeople were always decent and impeccable characters, but it leaves the audience in no doubt that evil entered the city from elsewhere. ${ }^{32}$

The physical and social environment of a place determines to a large extent how space and sound are experienced. Niall Atkinson has recently demonstrated how Renaissance Florence can be understood as an acoustic phenomenon. Atkinson explored how city sounds can be foundational elements in the creation of urban

Burgers et al. (eds.), Gedrukt in Holland, special issue of Holland, 26 (1994), 232. See about the network of Vander Plasse also J. Jansen, "Een volkomen bloementuin”. De Lijck-dichten (1619) voor Gerbrand Adriaensz. Bredero', Jaarboek Zeventiende Eeuw (2019), 49-65.

${ }^{28}$ See C. Kruyskamp, in G.A. Bredero, Stommen ridder, ed. C.H.A. Kruyskamp (Culemborg, 1973), 40. This suggests that the 'Summary' ('Inhoud') was not merely an overview of the content, but that it could also contain remarks about the relationship to the source text, as Bredero had done himself in the 'Inhoud' of Moortje and Spaanschen Brabander. See G.A. Bredero, Proza, ed. J. Jansen (Hilversum, 2011), $258,277$.

${ }^{29}$ P. Kotler et al., Marketing Places Europe: Attracting Investments, Industries, Residents and Visitors to European Cities, Communities, Regions and Nations (London, 1999).

${ }^{30} \mathrm{~J}$. Montgomery, 'Cultural quarters as mechanism for urban regeneration. Part 1: conceptualising cultural quarters', Planning Practice and Research, 18 (2003), 300-2.

${ }^{31}$ See Bredero, Proza, 230.

${ }^{32}$ J. Jansen, 'In en om Amsterdam: de wereld van Gerbrand Bredero', Ons Amsterdam, 65 (2013), 8-13. 


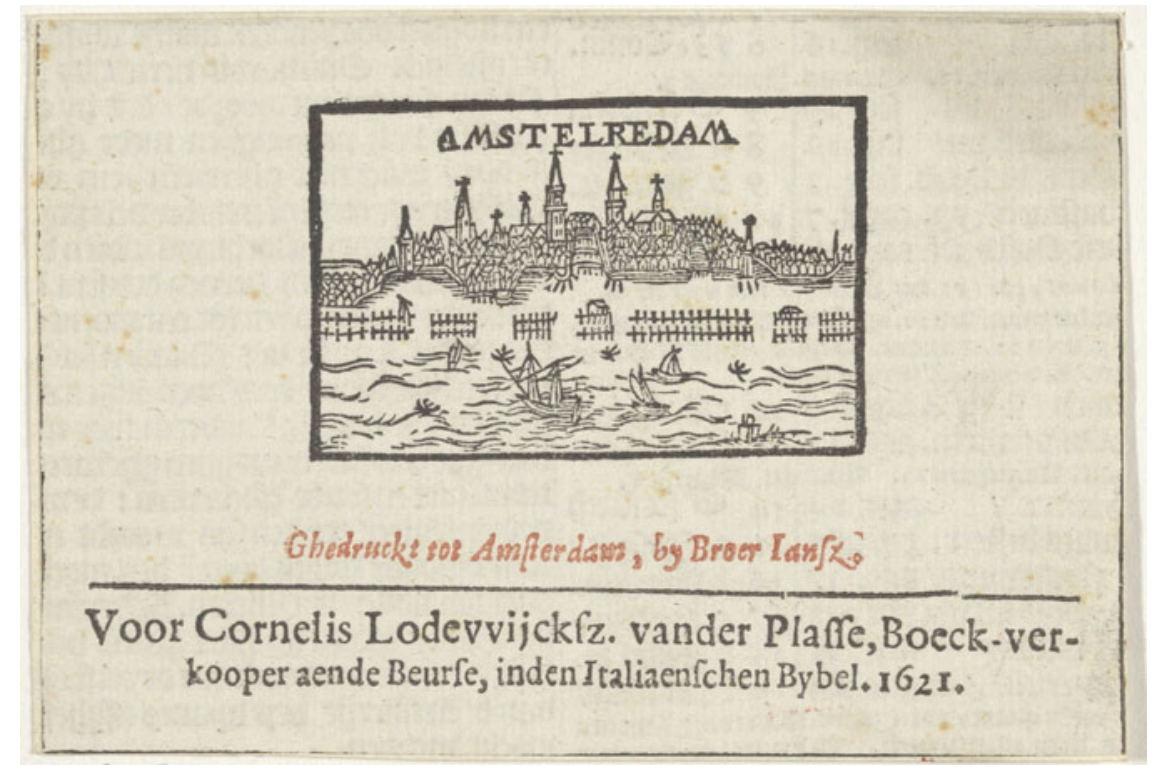

Figure 4. Silhouette of Amsterdam. Vander Plasse 1621, the printer (printed in red) is Broer Jansz. (Rijksmuseum Amsterdam)

communities and the spaces they inhabit. ${ }^{33}$ In the same way, the keynotes of the Amsterdam soundscape reflected the experience of city life, as illustrated in the walk that the shady, smooth-tongued Kackerlack takes through the marketplaces between the 'half-hoarse' voices of the market-women in Bredero's Little Moor (1615). Yet more noise. The proclamation in the Spanish Brabanter (1617) is announced by the bell of the Old Town Hall at the Dam square (vss. 1142-3): 'What is this I hear', an old man asks, whereupon his interlocutor explains: 'It is the bell of the City Hall - some proclamations will be read.' At that place, judgements were pronounced, and sentences executed. The bookstore of Vander Plasse was nearby, 'at the corner of the Bourse, in the Italian Bible' ('op de hoeck vande Beurse, inden Italiaenschen Bybel'), as almost every publication indicated on the title page (see Figure 5). The shop was also a meeting place that facilitated social and literary debate; Bredero's printed work became popular, and his name quickly spread from there. The bookshop thus contributed to Vander Plasse's image and ensured regular customers. Books published by Vander Plasse were exchanged with other booksellers and encouraged the distribution of Bredero's name to the rest of the country. ${ }^{34}$

\footnotetext{
${ }^{33}$ N. Atkinson, The Noisy Renaissance. Sound, Architecture, and Florentine Urban Life (University Park, PA, 2016), 151. Atkinson partly builds on Alain Corbin's history of bells in nineteenth-century rural France: Village Bells: Sound and Meaning in the Nineteenth-Century French Countryside (New York, 1998).

${ }^{34}$ B. van Selm, "'Het kompt altemael aen op het distribuweeren". De boekdistributie in de Republiek als object van onderzoek', in J.J. Kloek, and W.W. Mijnhardt (eds.), Balans en perspectief van de Nederlandse cultuurgeschiedenis. De productie, distributie en consumptie van cultuur (Amsterdam, 1991), 89-100.
} 


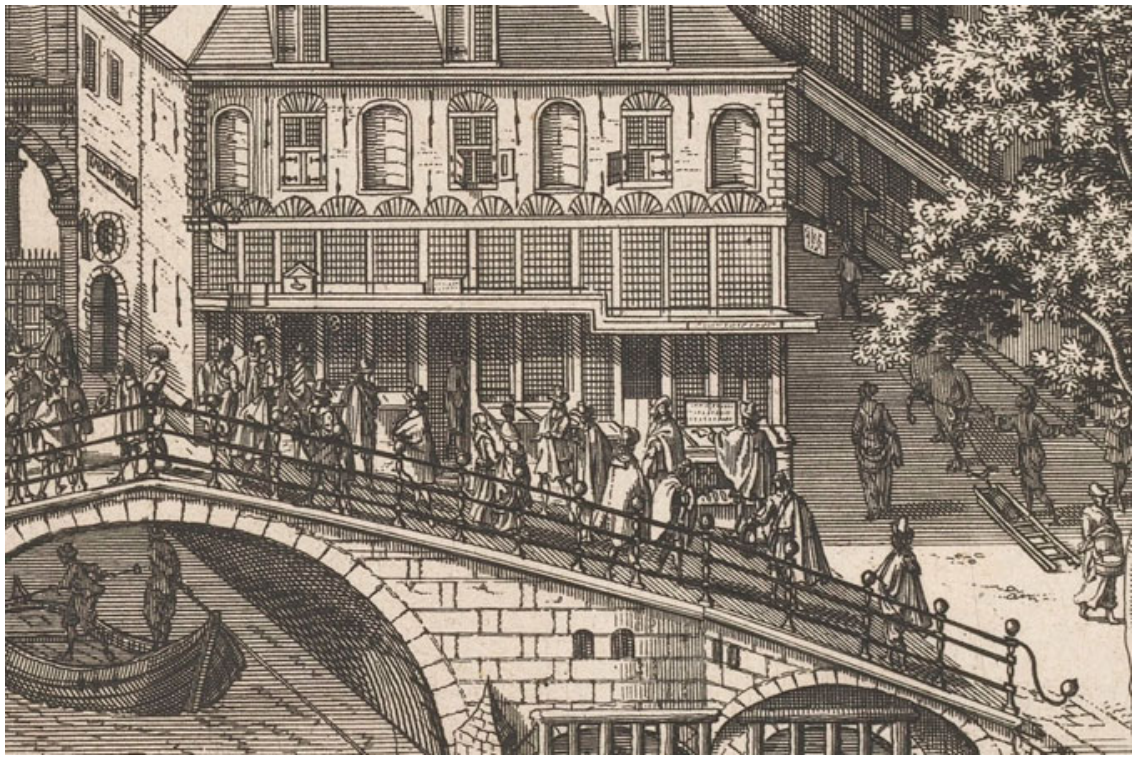

Figure 5. Amsterdam Bourse in the centre of the city. In 1611, on the corner of the Bourse, Cornelis Adriaensz. vander Plasse started his bookshop and somewhat later his publishing house. Engraving by P.H. Schut, in Filips von Zesen, Beschreibung der Stadt Amsterdam... (Amsterdam: Joachim Nosche, 1664), opposite p. 232. (www.bibliopolis.nl/beeldbank)

\section{Publishing strategies}

Bredero integrated the early seventeenth-century image of Amsterdam with all its grandeur and misery into his publications. Vander Plasse also used several strategies to integrate the image of the city into his publication of Bredero's work. Their commercial relationship really started when Vander Plasse became Bredero's permanent publisher in 1616 , in a period in which poetry was increasingly created outside the circle of rhetoricians and was no longer disseminated anonymously, but recognized as the personal work of an author. People interested in literature also became readers (and performers and singers), not merely hearers or listeners. ${ }^{35}$ With his publishing house and bookshop, Vander Plasse made the most of that development.

An important choice in those years was to connect the name 'Bredero' with the trademark 'Amsterdammer' (Amsterdam citizen). In December 1616, Bredero called himself 'a simple Amsterdam guy' ('een slechte Amstelredammer') in the introduction to his Little Moor. ${ }^{36}$ His local status was confirmed by his putting the word 'Amsterdammer' (Amsterdam citizen) under his name when he wrote an aphorism in an album amicorum in $1618 .{ }^{37}$ But as far as we know, the use of his citizenship in an epithet was initiated by his publisher, on the title page of a

\footnotetext{
${ }^{35}$ P. Tuynman, 'Petrus Scriverius, 12 January 1576-30 April 1660', Quaerendo, 7 (1977), 15.

${ }^{36}$ Bredero, Proza, 200.

${ }^{37}$ One of the few remaining personal handwritings of Bredero is this contribution to the album amicorum of Ernst Brinck (Stuiveling, Memoriaal, 164).
} 


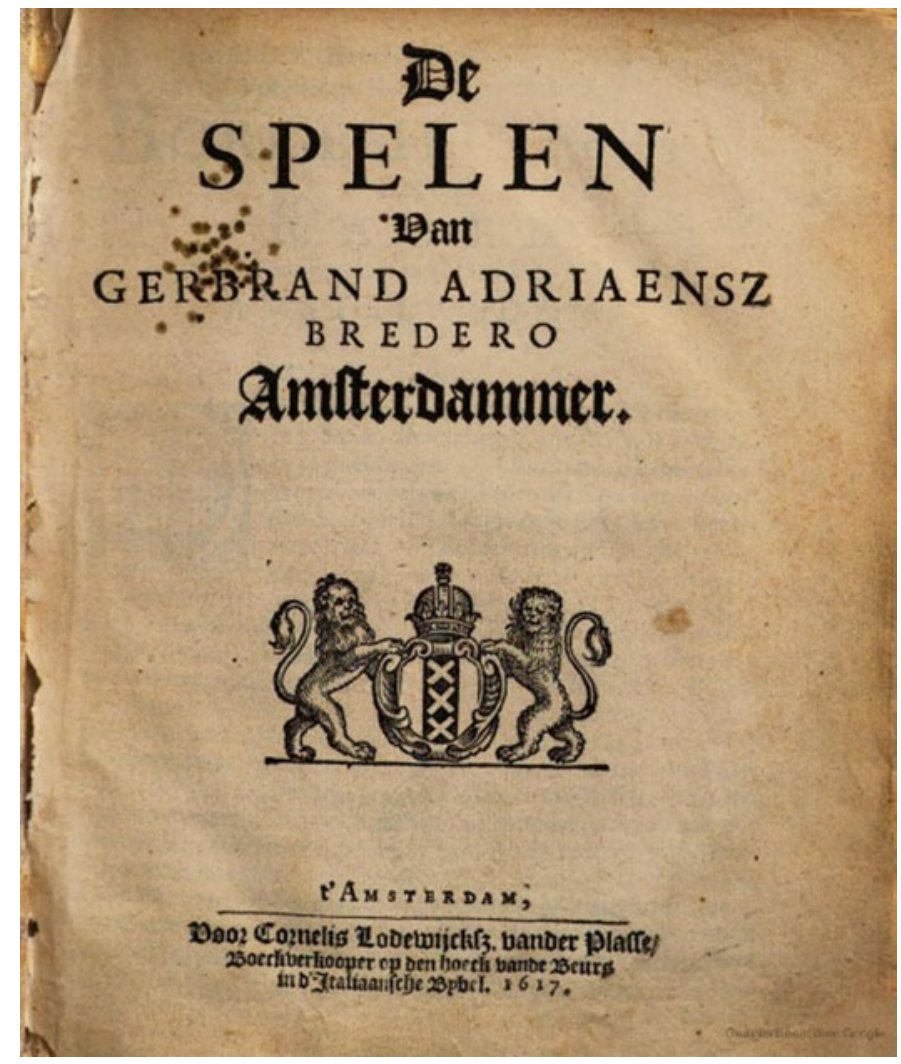

Figure 6. Title page of the collected plays by Bredero, published by Vander Plasse in 1617, showing the vignette of the city with its coat of arms: De Spelen van Gerbrand Adriaensz Bredero Amsterdammer (Amsterdam: Cornelis Lodewijcksz. vander Plasse, 1617), 'Boeckverkooper op den hoeck vande Beurs in d'Italiaansche Bybel, 1617' ('Bookseller at the corner of the Bourse, in The Italian Bible, 1617). (Rijksmuseum Amsterdam)

compilation of Bredero's plays in 1617: De Spelen van Gerbrand Adriaensz Bredero Amsterdammer (see Figure 6). The tripartite emphasis on the city in this edition indicates that a deliberate choice was made. First, the vignette bearing the city coat of arms adorns the title page. ${ }^{38}$ Moreover, for the first time, the epithet 'Amsterdammer' appears under the name of the writer - a phenomenon used earlier in the Neo-Latin tradition: Erasmus had been designated Roterodamus (from the city of Rotterdam) and later Dutch authors added the city they had come from, like Simon Stevin (from Brugues) and Otto van Veen (from Leiden). ${ }^{39}$ By the middle of the century, 30 years after Bredero's death, civic pride had become

\footnotetext{
${ }^{38}$ The city coat of arms was used earlier and elsewhere by Vander Plasse, as in his edition of Samuel Coster's Itys in 1615; its appearance may be attributable to the printer involved. Cf. Koopman, 'Nicolaes Biestkens', 125.

${ }^{39}$ De Weeghdaet beschreven duer Simon Stevin van Brugghe (Leiden: Plantijn, 1585); Q. Horati Flacci Emblemata..., studio Othonis Vaeni Batavolugdunensis (Antwerp, 1607).
} 
a more familiar concept. Publishers exploited the device for themselves, ${ }^{40}$ and several poets followed suit. Jan Vos (1610-67), for example, presented himself as a city poet by emphasizing the usefulness of his poetry for the city of Amsterdam. ${ }^{41}$ The poet Jan Zoet (1609-74) used the epithet 'Amsterdammer' more often than Vos, when he subscribed his name to letters and poems. Zoet was a real disciple of Bredero, and adopted his language as well as some of his (comical) themes. ${ }^{42}$ In the case of Zoet, however, 'Amsterdammer' seems to have been primarily used to identify the author, and it is doubtful whether it was also used as a marketing strategy.

In addition, Vander Plasse had asked the culturally influential Amsterdam doctor and author Samuel Coster (1579-1665) to write an introduction to this compilation of Bredero's plays in honour of the city. Dedicated to the burgomasters and city council of Amsterdam (Borgemeesteren ende Raden der Wijdt-beroemder Coop-stadt Amstelredam), Coster's introduction is suffused with the grandeur of Amsterdam, pointing, for example, at Bredero's successes at the local chamber of rhetoric, and announcing the opening of the Dutch Academy theatre. ${ }^{43}$ The dedication was addressed to the city council with good reason. It emphasized that Amsterdam's elite should support this endeavour in the spirit of Bredero. Possibly for that reason, too, the qualification 'Amsterdammer' has been put behind Bredero's name. Coster advises the magistrate to honour their talented fellow citizen as generously as their colleagues from antiquity did their own poets. ${ }^{44}$ All these elements confirm 'place' to be 'a social construct', the material setting of the city, but also our notion of this setting as a centre of cultural flowering and entrepreneurship. ${ }^{45}$ From then on, 'Amsterdammer' was Bredero's trademark, enduring after his sudden death in 1618 , to the present day. ${ }^{46}$

Vander Plasse's association of Bredero with Amsterdam has no direct equivalents in the rest of his publishing output, although he published the work of several other Amsterdam authors, including Samuel Coster. ${ }^{47}$ There must have been a reason, therefore, why he used this label for Bredero, and it involved both friendship

\footnotetext{
${ }^{40}$ When Willem Bontekoe's famous travelogue Iournael was published, the Hoorn bookseller Jan Deutel, who edited the diary for publication (1646), emphasized that it was a Hoorn affair. The author is therefore called here: Willem Ysbrantsz. Bontekoe van Hoorn (from the city of Hoorn); his ship was named the 'Nieuw Hoorn' (the new Hoorn) and the title vignette and dedication evoke the spirit of this city with various allusions.

${ }^{41}$ N. Geerdink, Dichters \& verdiensten. De sociale verankering van het dichterschap van Jan Vos (16101667) (Hilversum, 2012), 68.

${ }^{42}$ R. Cordes, Jan Zoet, Amsterdammer 1609-1674 (Hilversum, 2008), 20, 53, 66, 98. Parallels between both poets have been noticed by contemporaries and nineteenth-century critics. See ibid., 43, 46, 66 .

${ }^{43}$ G.A. Bredero, De Spelen van Gerbrand Adriaensz Bredero Amsterdammer (Amsterdam: Cornelis Lodewijcksz. vander Plasse, 1617), fol. (†)3r (dedication by Samuel Coster to the burgomasters and magistrate of Amsterdam).

${ }^{44}$ The dedication by Coster was also in this respect directly influenced by P.C. Hooft's Reden vande Waerdicheit der Poesie (c. 1614). See P.C. Hooft, Rede over de waardigheid van de poëzie. Reden vande Waerdicheit der Poesie, ed. J. Jansen (Amersfoort, 2005), 9.

${ }^{45}$ See Heebels, Van Aalst and Atzema, 'Places, publishers and personal ties', 256.

${ }^{46}$ For example, J.A.N. Knuttel, Bredero: poëet en Amsterdammer (Amsterdam, 1968).

${ }^{47} \mathrm{~A}$ chronological list of Vander Plasse's publications has been compiled by P.J. Verkruijsse: http://cf. hum.uva.nl/bookmaster/plasse/index.htm (accessed 31 Jan. 2020); see also Jansen, 'Drie decennia boekenzorg, 57.
} 
and marketing. Bredero was billed as a real city poet who gave Amsterdam a place in most of his successful literary texts. Furthermore, Vander Plasse, who started his publishing business as a sideline to his bookshop, could select his publishing tasks, which limited his list to a mere 150 publications. Bredero's work represented a significant part of it: some 40 editions (see Figure 2).

The two had been friends, but there was a business relationship as well, as they depended on each other's productions. The relationship changed after Bredero's death. Vander Plasse was the heir of Bredero's talent, but also the caretaker and reconstructor of his not yet published work, more than half of his writing. In the autumn of 1618, shortly after the funeral, Bredero's 'last play', Stommen Ridder, was performed at the newly opened Amsterdam theatre. Vander Plasse published it hastily, adding a significant collection of 27 funeral poems, the Lijck-dichten. The continued impact of Bredero's unexpected death resonates in these poems, written by friends and relatives of both Bredero and Vander Plasse. It was a local matter, and thus a product of the publisher's local network, as some of the poets were members of the Amsterdam chamber of rhetoric or of the Academy, others friendly engravers and painters, townsmen, or apparently just customers of his bookshop. Vander Plasse collected all he could get in the short term. ${ }^{48}$ Such a separate edition of funeral poems, a completely new initiative inasmuch as it concerned a deceased literary author, must have caught the eye. ${ }^{49}$ The content of these elegies and the status of their writers (Amsterdam friends) underline the fact that Bredero was still their city poet. In the meantime, he became more than just a local hero. Vander Plasse's publishing activities ensured that Bredero's texts were also loved outside Amsterdam. In 1622, for example, a pirate edition was published by the Rotterdam publisher and bookseller Pieter van Waesberge. Under the title Alle de spelen van Gerbrand Adriaensz Bredero, Amsterdammer (All the plays by G.A. Bredero, Amsterdam citizen), he disseminated an unauthorized reprint of the edition by Vander Plasse from 1617.

The posthumous portrait of Bredero, as far as we know, the first portrait of the author, featured prominently on the title page of the Lijck-dichten (see Figure 7). It was engraved by Hessel Gerrits, a famous engraver, cartographer and publisher, with his own publishing house and workshop at the Damrak nearby. The portrait must have borne a clear resemblance to the author, in view of its status among the funeral poems. For those who had not had the chance to know Bredero personally, and for later generations, it offered a valuable addition to the little we know about the author's personal life. The portrait was also included in later publications, such as the Merry Song Book (1621) and the Large Song Book (1622). Bredero's face has been framed in a laurel wreath, with his famous dictum 't kan verkeeren' ('it is all in the game') above. Beneath the portrait, the day and hour of his birth and death are engraved.

After 1618, the publishing of Bredero's work became a core task for Vander Plasse. Among all his publications, Bredero's texts had a prominent place, amounting to more than half of his fund (see Figure 2) ${ }^{50}$ By providing informative and

\footnotetext{
${ }^{48}$ See Jansen, “"Een volkomen bloementuin”, 58.

${ }^{49}$ Previously, only the Dutch poets Matthijs de Castelein and Karel van Mander were commemorated with one or more funeral poems. Bredero had a whole collection of them written in his honour.

${ }^{50}$ Grootes, in Bredero, Schyn-heyligh, 12.
} 


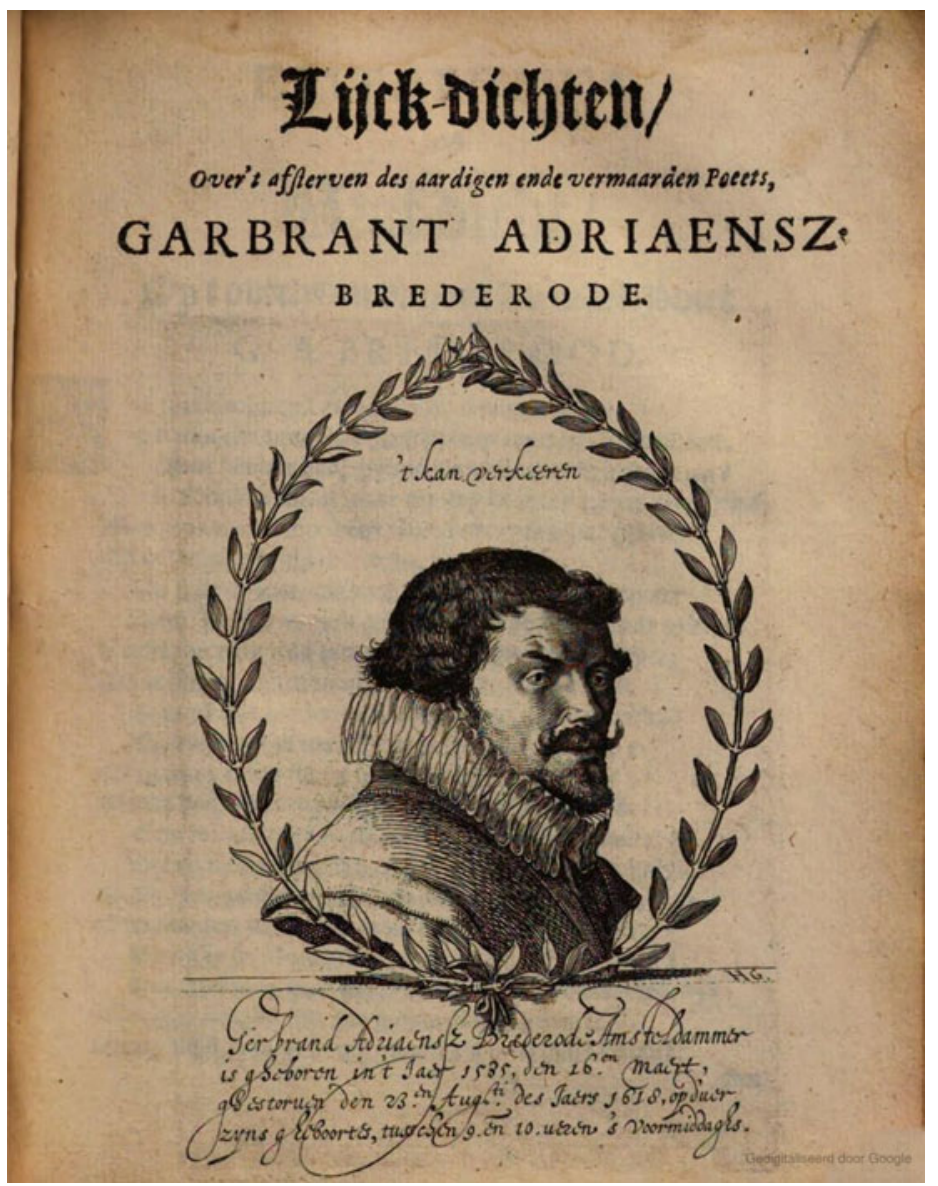

Figure 7. Title page of the Elegies (Lijck-dichten) for the death of Gerbrand Bredero. The elegies were published by Cornelis vander Plasse in the first edition of Bredero's play Stommen ridder (1619), after this separate title page. Here, the portrait of Bredero is shown for the first time; above his head his life motto reads: 't kan verkeeren' ('it is all in the game'). Beneath the portrait, the day and hour of his birth and death are engraved. (Rijksmuseum Amsterdam)

attractive introductions to several posthumous editions, Vander Plasse contributed to the promotion, prestige and the symbolic capital of Bredero's talent and work. These introductions upheld Bredero's image and supported reputation building. ${ }^{51}$ Years after his death, Bredero's readers kept looking forward to new verses by their beloved author. The publisher happily catered to their needs, advertising future publications of Bredero's songs and plays in various books. In the introduction of an enlarged edition of the Farces (1622), he announced that he was engaged with Bredero's plays Angeniet, Schyn-Heylich, 'and also...a play based on the little

\footnotetext{
${ }^{51} \mathrm{C}$. Banou, Re-Inventing the Book: Challenges from the Past for the Publishing Industry (Amsterdam, 2017), 58-60. Chapter 3 of this study focuses on publishing strategies used in the past, for example, in what way publishers tried to exploit reader engagement. The role of patronage is not addressed here.
} 
song Het daghet uyt den Oosten, etc. as well as the new Large Song Book'. ${ }^{52}$ This kind of notification may be considered a publishing strategy, as described by Christina Banou in Re-Inventing the Book: Challenges from the Past for the Publishing Industry (2017). The material functioned as an advertisement and helped in the process of (further) shaping the publisher's identity. ${ }^{53}$

Vander Plasse took pains to appear as a careful editor who was tirelessly devoted to collecting Bredero's autographs throughout the city.

Since I know that you, art-loving and desire-loving Reader, are very fond of the lessons and poems of the very famous poet, the late Gerbrant Adriaensz. Bredero, I have collected all his work, written by his own hand, not without great difficulty and high costs. Indeed, when I found writings of his with whosoever, I have pulled them out of their hands, making my best efforts to dedicate them by their value as gracefully as possible to you, benevolent Reader. ${ }^{54}$

This image of a dedicated publisher was strengthened by a few introductory essays in which Vander Plasse suggested that he had matched the published text as closely as possible to the intention of the author. By describing this personal process of collection, the attention of the reader is drawn to the activities of the publisher in the city's community. In one of these essays, he even suggested that his version of Bredero's text did justice to the 'right scent and proper meaning of the sweet sayings of the author' ('rechten geur ende eyghen sin van des Dichters soete spreucxkens') something that a rival publisher did not, on the basis of a slovenly copy, as Vander Plasse meaningfully noticed, suggesting his personal relationship with the author. ${ }^{55}$

This emphasis on his personal efforts to obtain and edit Bredero's manuscripts was more than mere self-advertisement. Unlike the manuscripts of authors such as P.C. Hooft and Constantijn Huygens, those of Bredero must have rarely been dated, nor properly organized. ${ }^{56}$ The texts of the plays, such as those of the farces, probably were partly reconstructed by the publisher from the actors' scripts that he had obtained. ${ }^{57}$ The texts of the songs, too, must have been gathered in various ways.

\footnotetext{
${ }^{52}$ G.A. Bredero, Kluchten (Amsterdam: Cornelis Lodewijcksz. vander Plasse, 1622), fol. ${ }^{\star} 1 \mathrm{v}$ (in Dutch): 'Den voorsz Cornelis vander Plasse heeft teghenwoordigh onder handen te drucken G.A. Brederoos Angniet. De Schijn-Heyligh, ende oock op het Liedjen Het Daget uyt den Oosten, etc. Als mede het nieu groot Lied-boeck, verçiert met vele konstige Figuren, ende met meer als twee hondert nieuwe Liedtjens, die noyt voor desen in druck zyn gheweest, alles begrepen onder dit voorsz Octroy, die alle Liefhebbers, door den druck, eerst-daedhs [sic] vertoont sullen werden. Vaert wel.'

${ }^{53} \mathrm{Banou}$, Re-Inventing the Book, 4-8.

${ }^{54}$ C.L. vander Plasse, 'Den drucker tot den leser' (the printer to the reader), in Bredero, Kluchten, fol. E2r (in Dutch): 'Vermidts ick U.E. konst-gierighe ende lust-lievende Leser, weet seer gheneghen te wesen tot de lessen ende ghedichtselen des E. seer vermaerden Rymer, Gerbrant Adriaensz. Brederode, salig. diens wercken ick alle, met ziin eyghen handt gheschreven, niet sonder groote moeyten ende diere kosten, hebbe by een versamelt, Iae een yegeliick by wien ick ziin schriften vondt, de selve als uyt de handen ghebroken, arbeydende omme die nae hunne weerde op het cierliickste U.E., goetwillighe Leser op te dragen.'

${ }^{55}$ Bredero, Kluchten, fol. E2r.

${ }^{56}$ See G.A. Bredero, Verspreid werk, ed. G. Stuiveling and B.C. Damsteegt (Leiden, 1986), 27.

${ }^{57}$ About the copy of Bredero's Miller: J. Jansen, 'Bredero's Klucht van de molenaar in twee vroege drukken. Een vergelijking van de editie Verberg (1618) en de editie Vander Plasse (1619)', Tijdschrift voor Nederlandse taal en letterkunde, 136 (2020), 2-19.
} 
More than half of what was issued in the Large Song Book of 1622 - some hundred songs - had not been published before. Vander Plasse also arranged that incomplete plays, which Bredero had only begun, were finished by carefully selected Amsterdam poets, according to the publisher's statement at high costs and with great difficulty on his part. The last play was not completed until 1638, 20 years after Bredero's death. In the preface, Vander Plasse stated that he had kept the manuscript of the unfinished play for a long time in his possession, 'because hardly any one dared to carry out the continuation of it' ('om datter qualijck yemandt wilde de handt aen steecken om voort te maecken'). At last he had succeeded in his aim. ${ }^{58}$ Such activities are a clear sign of his persistent dedication.

From a city branding perspective, a crucial question continues to be how the publisher integrated the early seventeenth-century image of Amsterdam into his publications of Bredero's work. To the three dimensions of place distinguished by Agnew - the geographical, contextual and emotional dimensions - Steven Hoelscher has added a fourth: 'Place as a social construction'. ${ }^{59}$ The city experienced an unprecedented flowering. The population was growing rapidly, and the number of books being produced and sold was correspondingly high. ${ }^{60}$ Capital and power may influence human creativity, and involve social, political and economic processes. The city functions as a 'material environment', an open area for the accomplishment of diverse social relations, ranging from family ties to economic and power relationships. ${ }^{61}$ The Amsterdam of Vander Plasse and Bredero should not be seen as a fixed notion, therefore, but as a flexible construct that, under the influence of various individuals and changing social relationships took different forms, subject to varying interpretations. ${ }^{62}$ The early modern bookshop and the publishing house should be considered places that were constantly (re)made by individuals and social practices. ${ }^{63}$ As publishers took financial risks with every publication, they were looking for safety by establishing collaboration, by requesting privilege in the face of unauthorized pirate prints, by sales on subscription and by acquiring contributions from patronage. ${ }^{64}$ There are no reasons to assume that Vander Plasse was an exception in this respect.

Research into the contribution of Vander Plasse has shown yet other strategies that contained a commercial component but were also a manifestation of the publisher's devotion. After Bredero's death, in an introduction 'To the reader' (1620,

\footnotetext{
${ }^{58}$ G.A. Bredero, Het daget uyt den Oosten, ed. B.C. Damsteegt (Culemborg, 1976), 46.

${ }^{59}$ S. Hoelscher, 'Place part II', in J. Agnew and J.S. Duncan (eds.), The Wiley-Blackwell Companion to Human Geography (Chichester, 2011), 251.

${ }^{60}$ See C. Lesger, The Rise of the Amsterdam Market and Information Exchange. Merchants, Commercial Expansion and Change in the Spatial Economy of the Low Countries, c. 1550-1630 (Burlington, 2006), 21457; Hoftijzer, 'Metropolis of print'.

${ }^{61}$ D. Massey, Space, Place, and Gender (Minneapolis, 1994), 121. See D. Bellingradt and J. Salman, 'Books and book history in motion: materiality, sociality and spatiality', in D. Bellingradt, P. Nellis and J. Salman (eds.), Books in Motion in Early Modern Europe. Beyond Production, Circulation and Consumption (Basingstoke, 2017), 8-9 ('Spatiality').

${ }^{62}$ See E.S. Casey, The Fate of Place: A Philosophical History (Berkeley, 1997), 286; Heebels, Van Aalst and Atzema, 'Places, publishers and personal ties', 257.

${ }^{63}$ See Heebels, Van Aalst and Atzema, 'Places, publishers and personal ties', 257.

${ }^{64}$ See Van Rossem, Het gevecht met de boeken; Bredero's dedications to drama published by Vander Plasse, like Moortje and Spaanschen Brabander, bear witness to patronage (cf. Bredero, Proza, 154-69).
} 
repeated in 1632 and 1638), Vander Plasse emphasized his great efforts to acquire Bredero's significant writings ('zinrijcke geschriften'). He had 'industriously collected them, in the south and the north' ('Zuyden ende Noorden met alle naerstigheyt by een vergadert'), and was hurrying to have them printed. ${ }^{65}$ This haste should be considered in conjunction with competition, in and outside the city. In the introduction to the Large Song Book (1622) Vander Plasse proclaimed that he had struggled to obtain all songs with 'incredible difficulty'. ${ }^{66}$ Several times he tried to get the publishing rights for Bredero's work. He managed to obtain them in 1622: over six years, he forced competitors into a supporting role, as he was allowed to do, as a 'Bookseller and burgher of the city of Amsterdam' ('Boeck-verkooper ende Borgher der Stadt Amstelredam'), to print or let print, publish and sell the Works 'of the excellent Amsterdam poet' ('vanden treffelijcken Amsterdamschen Poët') Bredero. ${ }^{67}$ Under each of the songs in the Large Song Book he put Bredero's name or device, impeding the reuse of separate poems in other collections of poems. ${ }^{68}$

Vander Plasse was continuously building his image as a reputable and honourable publisher, who, on the basis of Bredero's autographs, offered a pure text. This image was confirmed by his preliminary remarks more than once, sometimes as an attempt to silence competitor-publishers. ${ }^{69}$ These were pushed aside between 1629 and 1644. A reprint (1632) of the Spanish Brabanter published by the Leiden publisher Josephus vander Nave is a clear exception. In the following years, interest faded somewhat, after Vander Plasse had reissued a few plays in 1633. In 163436 , not a single publication by Bredero appeared. However, in the next two years, a final run started when Vander Plasse published a new play by Bredero as well as the so-called Complete Works.

At every opportunity, Vander Plasse decided which information his paratexts would provide to the reader, corresponding to his own objectives, his own values and the (mostly unwritten) publishers' laws. ${ }^{70}$ The preliminary considerations of Vander Plasse had to replace the dedications and prefaces written by Bredero himself during his life. Those by Vander Plasse are focused on the author, on his talent and the nature of it. But they also reflect the city's accent and strengthen the identity of Amsterdam. This is clearly shown in the publication of the Complete Works (Alle de wercken) in 1638, of which the three-part introduction may be considered as Vander Plasse's final farewell to his former friend, at least from an ex ante point

\footnotetext{
${ }^{65}$ G.A. Bredero, Nederduytsche Rijmen (Amsterdam: Cornelis Lodewijcksz. vander Plasse, 1620), fol. A2r.

${ }^{66}$ C.L. vander Plasse, preface to Bredero, Boertigh, amoreus, en aendachtigh groot liedboeck. Vercierd met vele klinckers, oock bruylofds en klaegdichten (Amsterdam: Cornelis Lodowijcksz. vander Plasse, 1622), 'Voorrede Tot den Sang-gierighen-Leser', 15.

${ }^{67}$ Bredero, Boertigh, amoreus, en aendachtigh groot liedboeck, fol. ${ }^{\star} 1 \mathrm{v}$. See E.K. Grootes, '9 april 1622: Cornelis Lodowijcksz. van der Plasse ontvangt een privilege van de Staten-Generaal voor het drukken van alle werken van Bredero. Liedboeken', in M.A. Schenkeveld-Van der Dussen (ed.), Nederlandse literatuur, een geschiedenis (Groningen, 1993), 202-6; P.G. Hoftijzer, 'Nederlandse boekverkopersprivileges in de zeventiende en achttiende eeuw', Jaarboek van het Nederlands Genootschap van Bibliofielen, 1 (1993), 4962; Rasterhoff, Painting and Publishing, 114-15; Van Rossem, Het gevecht met de boeken, 57ff (six years was the standard period).

${ }^{68}$ See Stuiveling, in Bredero, Verspreid werk, 37.

${ }^{69}$ See Jansen, 'Bredero's Klucht van de molenaar'.

${ }^{70}$ Banou, Re-Inventing the Book, 4; cf. Van Rossem, Het gevecht met de boeken, 10.
} 
of view. According to Eddy Grootes, the prefatory part may be directly related to the 'renaissance' of Roman glory in Amsterdam. ${ }^{71}$ At the same time, it offered the publisher the opportunity to raise Bredero to the level of the classics, as a second Terence or even 'our Amsterdam Terence'. The publication opens with a dedication by Vander Plasse to the Amsterdam burgomaster Albreght Koenraed, in which he describes the history of theatre from antiquity in broad outline, against which Amsterdam and Bredero could measure themselves:

Between and above the Dutch cities, Amsterdam was full of poetry and drama for some time. Among other talented men, Gerbrand Adriaensz Bredero displayed his talent, following his inborn nature and his own inclination. $\mathrm{He}$ rightly showed that he had enough spirit to execute a splendid thing and that he would have produced work with greater experience and with more excellence, if he was not lacking in knowledge of language, and if he didn't get help of the nature of art and learning. Because without that [lack], according to learned people he would have equalled Aristophanes, Terence, and Plautus (don't blame them this impertinence). Indeed, not the least opinions wholeheartedly stand by saying that some of his plays do not give an inch to Plautus...The appeal of his verses made the printing press crack many a time, and the great demand has brought me to publish Bredero's work again, as his work went out of print... Our book will be not a little adorned and appeal to our community by the name of such a man, who was so useful and subservient for the city and for all of us during many years. ${ }^{72}$

The last sentence describes how the city will benefit from reading Bredero's work, a commercial trick of course, but also the deliberate use of a concept, a brand promise. The dedication is followed by a long exposition on plays and theatres in antiquity. ${ }^{73}$ As Grootes has discussed, this exposition, derived from an introduction to a French translation of Terence's Andria by Charles Estienne, offered the readers

\footnotetext{
${ }^{71}$ E.K. Grootes, 'Een theaterhistoricus in 1638 ? Het voorwerk van Bredero's Alle de wercken en de kennis omtrent het theater uit de Oudheid in de zestiende en de zeventiende eeuw', Spektator, 12 (1982-83), 471 (especially on the second part of the prefatory material: a large explanation of the classical theatre).

${ }^{72}$ C.L. vander Plasse, dedication to Albregt Koenraed, in G.A. Bredero, Alle de wercken So Spelen, Gedichten, Brieven en Kluchten van den gheest-rijcken Poëet Gerbrand Adriaensz: Bredero Amsterdammer, Verbetert en daer by ghevoeght eenighe die noyt voor desen ghedruckt zijn gheweest (Amsterdam: Cornelis Lodewijcksz. vander Plasse, 1638), fol. A4r-v (in Dutch): 'Onder de Nederlandsche steden ging Amsterdam daer van [nl. van toneel en dichtkunst] eenen tijdt lang boven anderen zwanger; daer neffens andere vernuften Garbrand Adriaens Brero zijn vernuft uytgoot, zoo als zijn aengeboren aerd en natuur hem dat instortte, wel toonende dat hy geest genoegh had, om wat treffelijckx, en zijn dingen beslepener en beschaefder met meer pits uit te voeren, indien het hem niet aen taelkunde gemangelt, en de natuur van de kunst en geleeleertheyd [sic] hulp gekregen had: want zonder dat, hy en zoude, na het gevoelen van geleerde harssens, Aristofanes Terentius nochte Plautus (vergeef hem deze vrypostigheid) niet toegeven: ja geen geringe oordeelen houden wel volmondigh staende, dat eenige spelen Plautus niet eenen voet wycken durven...D'aengenaemheid zyner veerzen dede de druckpars menigmael kraecken, en de groote treck beweegde my, alzo de druck weder uit was, Breroos wercken van nieuws aen te leggen...Ons boeck en zal oock niet weinig verciert zyn, en de gemeente toelachen met den naem van soo een' man, die de stad en gemeenen Staet veel jaeren lang zo nut en dienstig was.'

${ }^{73}$ Bredero, Alle de wercken, fols. B1r-C2r.
} 
a clear link to be established with the new Amsterdam theatre opened earlier that year (1638). ${ }^{74}$ Architecturally, it looked like a Roman theatre. It provoked Vander Plasse not only to publish this exposition but also to compare Bredero to Terence as a Terentius redivivus (a risen Terence). By comparing the Amsterdam situation to ancient theatre and authors, Vander Plasse put Bredero's work in a classical tradition. The same goes for Bredero as an author, who played his part in the renaissance of Roman glory in Amsterdam, due to his comedy The Little Moor (1617), an adaptation of Terence's Eunuchus. ${ }^{75}$ The geographical, contextual and emotional dimension of Amsterdam identified by Agnew, as well as the social dimension proposed by Steven Hoelscher, can be clearly distinguished in this prefatory material.

In the second half of the seventeenth century, the image of a close connection between Bredero and Amsterdam remained intact, helped by the preliminary and paratextual initiatives of the publisher. 'The influence of the cultural appearance of the publishing house on the reception of literary works' (De Glas) is clear. In 1665 , almost a half century after Bredero's death, the head of the city theatre, Tobias van Domselaer, loudly praised the author as 'our Amsterdam Terence' ('onzen Amsterdamsen Terentius'), whose comical plays excel in 'the old, sincere Amsterdam simplicity' ('d'oude, oprechte, Amsterdamse eenvoudigheidt'), showing that 'the spectators here in Amsterdam' were getting no less than Terence once offered his Roman public. Old Amsterdam people who had heard or read Bredero's Little Moor would think, according to Van Domselaer, that they were living 50 years earlier, when they heard the old market vendors extolling their wares. ${ }^{76}$ The laudatory description 'Amsterdam Terence' is found again and again during the eighteenth century. ${ }^{77}$ The typical historical Amsterdam atmosphere in his work, too, is often praised in nineteenth- and twentieth-century schoolbooks and literary histories. ${ }^{78}$ As a result, Bredero achieved a canonical status that has lasted until the present day. ${ }^{79}$ Due to Bredero's work and the initiatives of Vander Plasse, the culture of Amsterdam of the early seventeenth century has been repeatedly evoked, leaving diverse impressions on later generations, with these impressions superimposed on the city's identity. ${ }^{80}$ As a result, present-day Amsterdam has accepted Bredero with open arms as their historical city poet par excellence. His work has become part of a ritual of commemoration across the centuries. In the various Bredero celebrations and commemorations, almost always completely Amsterdam affairs, these impressions are reflected back into the place's culture, for example by way of statues, city festivals and open-air performances of scenes

\footnotetext{
${ }^{74}$ Grootes, 'Een theaterhistoricus in 1638 ?', 470.

${ }^{75}$ Ibid., 471.

${ }^{76} \mathrm{~T}$. van Domselaer, 'Geleerde en Dappere Mannen en Konstenaars', in O. Dapper, Beschryvinge van Amsterdam (Amsterdam, 1665), vol. V, 97.

${ }^{77}$ J.P. Naeff, De waardering van Gerbrand Adriaenszoon Bredero (Gorinchem, 1960), 40.

${ }^{78}$ For example, in studies by Jan ten Brink, Geschiedenis der Nederlandsche letterkunde (Amsterdam, 1897), 393; Naeff, De waardering, 85-9, 94; Van Stipriaan, De hartenjager, 146-53.

${ }^{79}$ See M.-Th. Leuker, 'Bredero und der literarische Kanon. Über Wechselbeziehungen zwischen Literaturgeschichtsschreibung und historischem Erzählen in den Niederlanden im 19. Jahrhundert', in E. Widder et al. (eds.), Manipulus florum. Festschrift für Peter Johanek zum 60. Geburtstag (Münster, 2000), 381-95; Van Stipriaan, De hartenjager, 144.

${ }^{80} \mathrm{M}$. Kavaratzis and M.J. Hatch, 'The dynamics of place brands: an identity-based approach to place branding theory', Marketing Theory, 13 (2013), 82.
} 
from his plays. ${ }^{81}$ They also strengthen the city's image, uniqueness and authenticity. ${ }^{82}$ On 16-17 March 1985, for example, 300,000 people flocked on to the streets of Amsterdam, around the Nes, the Oudezijds Voorburgwal and the Kloveniersburgwal, and partook in a street festival with scenes taken from Bredero's work. ${ }^{83}$

\section{Conclusion}

Gerbrand Bredero has belonged to the Dutch literary canon since the early nineteenth century. He stands out for his refined style, vibrant technique and the subtle way in which he gave his work a deeper meaning. Bredero, born and raised in Amsterdam, wrote songs and plays for his fellow citizens about local matters. This may have been an important, if not decisive, reason to use the epithet 'Amsterdam citizen'. Contemporaries were particularly fond of Bredero's jocularity in his Amsterdam scenes. The contribution of publisher Cornelis vander Plasse to the process of canonization was substantial. After Bredero died, about half of his oeuvre had yet to be published. Due to the commitment of this publisher we can still read and enjoy it. ${ }^{84}$ Bredero himself, the nature of his comical writings and personal life ensured that he would be forever associated with the city, as he still is today. ${ }^{85}$ Though it was not unusual in this period for publishers to connect an author with their place of origin or for authors to label themselves as citizens of a specific town, the way in which this publisher handled Bredero's work for so many years makes this case exceptional. The persistent use of the Amsterdam label in combination with the preliminary material (dedications), and the typical Amsterdam content and dialect of Bredero's comical plays and songs offered the publisher a crucial and persuasive tool to make this author more public, beloved and widely known.

The local labelling may have also been Vander Plasse's response to substantial cultural influences from outside Amsterdam, brought by immigrant artists from the Southern Netherlands and elsewhere. Bredero's accession to the canon has been advanced by the publisher's marketing strategies partly aimed at personal prosperity and profit. But the efforts of Vander Plasse reflect a personal aim as well, namely, to conserve and publish everything that had proceeded from the fruitful pen of his old school friend, in order to make his writings public or even successful. Wherever he could find a snippet written by Bredero, it had to be published

\footnotetext{
${ }^{81}$ Commissioned by the city's municipality, Piet Esser has made a bronze statue representing a scene from Bredero's Spanish Brabanter. The statue, located at the Amsterdam Nieuwmarkt, was revealed in 1968 on the occasion of the 350th anniversary of Bredero's death. See for the latest initiative: www.bredero2018.nl (accessed 16 Apr. 2020) (in Dutch). The past commemorations are discussed by Van Stipriaan, De hartenjager, 130-78, the recent ones by E. van Schaik, 'Het kan verkeren. Bredero in de eenentwintigste eeuw', Spiegel der letteren, 61 (2019), 57-68.

${ }^{82}$ See Riza, Doratli and Fasli, 'City branding and identity', 294.

${ }^{83}$ For an impression of the open-air performances, see the Bredero-festival (1985).

${ }^{84}$ Grootes, in Bredero, Schyn-heyligh, 12.

${ }^{85}$ For example, in 2018 by way of a digital exposition and a city walk: www.bredero2018.nl/wandeling (accessed on 16 Apr. 2020).
} 
- personal items such as love letters as well. ${ }^{86} \mathrm{New}$ verses came out gradually, after Vander Plasse had elaborately whetted his customers' appetites. In a few examples, he slightly adapted them, in which case he advertised his 'improvements' in overblown language on the title pages. There he shouts about the newness of the publication.

The role of Vander Plasse was prominent and decisive; it surpassed the 'condition-creating atmosphere' ('voorwaardescheppende sfeer') that De Glas attributed to the modern publisher. ${ }^{87}$ Vander Plasse fulfilled all conditions described by Christina Banou as possibilities for publishers to shape the literary oeuvre of an author and to make it beloved by a broad urban public. ${ }^{88}$ In this way, he was not only responsible for the publishing process, but also provided the readers with access to all published texts, promoting the work and adapting it to the market. He spread Bredero's word, expanding the Dutch lexicon. Moreover, he constructed his public, giving them stability by using the epithet 'Amsterdammer'. He established greater publicity for the person Bredero by way of the (posthumous) publication of his portrait. He gave information, too, leading the reader to other publications. And he initiated the comparison between Bredero and Terence, calling his friend a Terentius redivivus. Vander Plasse fully benefited from all the opportunities that presented themselves. He obviously also took note of the design of Bredero's work, looking after adequate diversification across different publics with various financial possibilities: a cheap little Merry Song Book (1621) versus an expensive variant, the Large Song Book (1622).

In this article, the literary and the urban research field has been combined by discussing how different types of city labelling are used as promoting or identifying strategies and how a seventeenth-century publisher and an author gave a multiplicity of meanings to the place of Amsterdam. As we have discussed, place may be perceived as a social construct where public interaction took place. Products take on the qualities of the places from which they come. Places where news and books were made and sold increasingly functioned as meeting points for citizens, for scholars and men of letters in particular, sometimes for political or religious factions. Therefore, the bookshop may also be regarded as a place of experience, being both a representation and a lived reality. As Heebels has pointed out, 'place is not an objective, fixed thing but involves a multiplicity of meanings given by actors who make use of that place' ${ }^{89}$ Amsterdam was the undoubted centre of Dutch publishing and the book trade in the seventeenth century, the bookshops situated close to the Dam square with its town hall. Given the triangular relationship between publisher, author and the city of Amsterdam, the location of the bookshop and

\footnotetext{
${ }^{86}$ Vander Plasse, in Bredero, Nederduytsche Rijmen, fol. A2r-v: 'versamelende alle de stucxkens van zyne soete Rijmpjens, hoe cleen sy oock zijn'.

${ }^{87}$ De Glas, 'Hebben uitgeverijen invloed', 302: 'as far as it...concerned types of publishing involvement that are needed to even publish a book, this involvement is always situated in the "condition-creating atmosphere" (for example the selection, editing, design, and exploitation of texts)' ('Voorzover het...ging om typen van uitgeverijbemoeienis die noodzakelijk zijn om überhaupt een boek te laten verschijnen, ligt deze bemoeienis steeds in de voorwaardescheppende sfeer (denk aan de selectie, tekstredactie, vormgeving, exploitatie)'.

${ }^{88}$ Banou, Re-Inventing the Book, 4 and passim.

${ }^{89}$ Heebels, Van Aalst and Atzema, 'Places, publishers and personal ties', 257.
} 
publishing house with all its local networks played an important part in the success and the marketing thereof.

During a mere thirty years, Vander Plasse initiated efforts to display Bredero's talent to his fellow Amsterdam citizens, by shaping an identity that ensured that the work was easily recognizable for the readers, achieving a lasting effect on the canonization of Bredero in past centuries. In his introductions, Vander Plasse systematically worked towards his own image as the one and only publisher of Bredero, stating that he provided a reliable text, on the basis of autographs, and claiming that he had knowledge of the author's intentions. ${ }^{90}$ His remarks support the impression that he published this work on the basis of a personal, 'communality-relationship', rather than on the basis of a mere commercial 'connectivity-task'. 91 Distinguishing between different publishing strategies enabled us to find an answer to the question of how urban place matters to publishers. Places influence publishers' networks and determine what perspective should be used to consider how readers buy and read books as a manifestation of urban culture. Further research could focus on the triangular relationship between publishers, authors and cities in the early modern period, by analysing the way in which city marketing, publishing strategies and reputations of literary authors are built on urban landscapes depicted in literary texts.

Bredero's original talent contributed to the success of his publisher and vice versa. The affective bonds between publisher and city were further strengthened by the successes of (the performances of) Bredero's comical and jocular verses. The scope of Vander Plasse's activities and strategies as a contribution to the current reputation of Bredero becomes obvious. From his own remarks it seems that he handled the literary heritage with care, but also that he published (almost) everything that Bredero had written. Do the Complete Works (1638) therefore offer the complete work by Bredero? This is an interesting question, especially when we realize that Vander Plasse will have neglected few if any of Bredero's autographs. The answer is: no. It is still difficult to explain why the publisher left out certain, much earlier published poems by Bredero (liminary poems, poetry in the Tragic Histories). As he must have been aware of these poems, only one realistic possibility remains. Cornelis vander Plasse kept these verses in reserve to publish later, aiming to create a pleasant surprise for the faithful readers and to renew their acquaintance with Bredero's work. However, this was not to happen. Bredero's childhood friend died a few years afterwards, on 2 September 1641.

\footnotetext{
${ }^{90}$ See Jansen, 'Drie decennia boekenzorg'.

${ }^{91}$ Heebels, Van Aalst and Atzema, 'Places, publishers and personal ties', 253-4 (see n. 26 above); cf. Grootes, in Bredero, Schyn-heyligh, 12-13.
}

Cite this article: Jansen J (2022). Branding in practice, or how an Amsterdam publisher used the city to promote Gerbrand Bredero (1585-1618). Urban History 49, 265-287. https://doi.org/10.1017/ S0963926820001030 